

\section{'Complications and Attacks on the Beauty of Unity': Le Corbusier and Louis Soutter}

KrzysztofFijalkowski

Detail from Louis Soutter, untitled, c. 193I. Ink drawing on page 60 of Amédée Ozenfant and CharlesEdouard Jeanneret, La Peinture moderne, Paris: Éditions Crès, 1925 (plate 8).

DOI:

10.1III/1467-8365.12262 Art History| ISSN 014I-6790 $X X|X|$ Month $X X X X \mid$ pages $X X-X X$
The work and ideas of Le Corbusier (Charles-Édouard Jeanneret, 1887-1965) continue to polarize opinion. Commonly considered the most influential architect of the twentieth century, his legacy extends to fields such as town planning, product and interior design, painting, graphics and above all theoretical writing. Yet in all of these his reception has been divided between those who see in him the arch rationalist, an avatar of mechanized mass culture and a figurehead for high modernism's toughest functional and constructive aesthetics, and those who read him instead as imbued with a more 'artistic' and visionary sensibility, a poet of the applied arts, even a latent surrealist - with all the appeal to the irrational and anti-cultural the latter assertion might imply. ${ }^{1}$ These apparently contradictory strains are already signposted in Le Corbusier's series of innovative and influential early writings published during the 1920 s - it was arguably on these rather than his completed buildings that his initial reputation rested - in which an ambitious polemic on art, architecture and design is presented in a signature graphic format combining a distinctive use of text, image and typography. Largely based on articles first presented in the journal L'Esprit Nouveau, edited by Le Corbusier and the painter and theorist Amédée Ozenfant between 1920 and 1925 and the principal organ for their purist art movement, books such as Vers une architecture (Towards a New Architecture) or L'Art décoratif d'aujourd'hui (The Decorative Arts of Today) laid out a vigorous and deliberately provocative argument for a progressive aesthetic that would reconfigure the roles and relationships of art, architecture and design, stripped of all artifice to reveal objects, images, homes and environments fit for life in a machine age. Written and published in Paris more or less contemporaneously with the Parisian dada group and the founding of the surrealist movement, the polarity of European high modernism seems clearly activated by mid-decade: logic against the absurd, purity against the unconscious, social cohesion against its others, whitewash and concrete against poems.

But of all the responses to the challenge of Le Corbusier's writings, among the most surprising and least known, certainly the most moving and hardest won, are kept in a modest cardboard box in the archives of the Fondation Le Corbusier in Paris; they are the work of the architect's own cousin Louis Soutter (1871-1942), an 'outsider' artist whose entire mature career was spent in an institutionalized environment against his stated will. Three of Le Corbusier's books, bound together in two volumes, have been painstakingly and completely covered in an extraordinary series of ink drawings - not so much a work of illustration (after all these books are already illustrated with printed photographs and drawings) as colonizations, even 
détournements of the publications as both arguments and material objects. These unique books, with their divergent intellectual systems driven in complex and ambivalent ways by their text/image tensions, bear witness to one of the more unexpected encounters of European modernism, and might be read as a key to triangulate the relative positions of the latter's apparently opposing markers, so as to test what happens when against expectation they happen to meet. At first glance, two mutually exclusive sensibilities appear to have collided, one powered by a sophisticated logic, the other by a destabilized subjectivity. But which one is which?

The books in question are L'Art décoratif d'aujourd'hui (the major focus here) and Le Corbusier's and Ozenfant's La Peinture moderne, bound together in one volume under the title 1925 Expo. Arts Déco., and a slightly later work Une maison - un palais of 1928; their modification is dated by Michel Thévoz, Soutter's most important biographer and commentator, at 1931, a contention supported by the dossier of correspondence between the cousins also held in the Fondation archive. ${ }^{2}$ Both the books and the relationship to which they testify have been cited and in some cases discussed at some length in the literature on Soutter, though until recently access to the books' content has been largely limited to print reproductions rather than public exhibition of the objects themselves; but the extensive studies devoted to Le Corbusier, in contrast, have scarcely commented on them, despite Le Corbusier devoting an article to the artist in 1936 and reproducing an image from the books in a special issue of L'Architecture d'aujourd'hui in $1948 .^{3}$

In several ways, and given the far wider appreciation of the work and ideas of Le Corbusier (driven in part by his flair for self-promotion), it is Soutter who will always remain the hidden correspondent in this exchange. Indeed, in contrast to the broad shadow cast by Le Corbusier's reputation across a range of disciplines, the place of Louis Soutter within the canon is unstable and contested in several ways. Born in Morges near Lausanne, the young Soutter showed signs of brilliant promise, rejecting early studies in architecture in Geneva and Zurich in order to study the violin in Brussels, a discipline to which he would return professionally throughout later decades but which vied for prominence with his other considerable gift for painting and drawing, studied next in Switzerland and Paris. ${ }^{4}$ Married to an American from a wealthy background, Soutter emigrated to the United States and by 1898 was Head of Fine Art at Colorado College, Colorado Springs. A successful if unremarkable career built around his ability as a talented but rather conservatively academic painter seemed in prospect, but over the coming years Soutter's health began to deteriorate. According to Thévoz, this very promise of success acted as a trigger in the face of the artist's overwhelming feelings of guilt, failure and impotence. Returning to Switzerland in 1904 in a state of nervous and physical collapse, and with his father's death that same year adding to the already morbid, unpredictable and conflictual leanings to which he increasingly became prey, Soutter spent the next decade and a half continuing to work as a musician but displaying ever more eccentric behaviour, accompanied by financial problems and a tendency to withdraw from everyday social interaction, quickly alienating his family and most of his friends. By 1922, his demeanour having become intolerable to his family, Soutter was placed first in a Maison de Santé and then the following year in the Asile de Jura at Ballaigues, an isolated village some forty kilometres from Lausanne. Though the latter was not, as has sometimes been asserted, a psychiatric asylum but an old people's home, this nevertheless represented an institutionalized environment, experienced by Soutter (who was only in his early fifties) as a miserably confined, controlled regime from which he repeatedly made pleas to be liberated. Even if right from the start of his stay 
he was allowed access to the village and rambles in the countryside, and later longer visits to friends as far away as Zurich, it was apparently clear to all concerned (and presumably at some level to Soutter himself) that he was temperamentally unable to adapt to independent life outside this home, where he spent the remaining nineteen years of his life.

This history might have been nothing more than one unfortunate case of decline among many, were it not for the fact that upon admission to the Asile de Jura his artistic activity suddenly and dramatically flowered into an entirely unprecedented phase lasting until his death, centred above all on ink drawings executed, to begin with at least, on any available paper support and produced in their hundreds and thousands (later extending to paintings made with his fingers rather than a brush). The academic conventions of his earlier work vanished, the artist abandoning realistic depictions of genre scenes to embrace instead a dense, teeming and nervously hatched circus of an interior life that veered from thickly populated figurative images (often with classical or biblical overtones) to imaginary cities and extravagant decorative motifs. If, unsurprisingly, the Asile's staff initially declined to treat this work seriously, over the course of the 1930s a small but growing number of supporters and collectors came to appreciate and promote Soutter's output (one of the most vigorous of whom, as we shall see, was Le Corbusier). After his death, however, it would above all be the interest of Jean Dubuffet and the rise of his notion of art brut that would guarantee Soutter's reputation, thus categorized first and foremost as belonging to a strain of unsanctioned, 'raw' artistic production characterized in particular by the mental welfare of many of its protagonists. If Soutter's work has most often been presented in the context of art brut and scrutinized for evidence of its maker's psychiatric condition, however, his place in this classification is problematic: Soutter's training and successful early career as a professional artist, albeit of an entirely different water, disqualified him from Dubuffet's eventual revision of his category of art brut during the 1960s, relegating him to a status halfway between this and 'cultural art'. ${ }^{5}$ The artist's legacy, then, remains in a kind of taxonomic limbo, sometimes noted for its prescient anticipation of more recent bodies of work but for all that seen as an isolated, inwardly facing obsession driven by suffering and cut off from the currents and culture of his time. ${ }^{6}$

It would seem that Le Corbusier first became aware of Soutter's work around 1927, most probably through his family in Geneva or Ponts-de-Mastel. Soutter's maternal grandfather was the brother of Le Corbusier's paternal grandfather; Soutter's uncle, furthermore, was the father of Pierre Jeanneret, Le Corbusier's long-term architectural collaborator during this period. ${ }^{7}$ Over the next decade an intense if episodic relationship developed between the two men, notably with Soutter both inviting Le Corbusier to Ballaigues and offering him hundreds of drawings, some of the finest of his work. Notwithstanding their family kinship, Le Corbusier could not have failed to be struck by the distance between the two men's temperaments, ideas and above all artistic production - indeed his published writing on his cousin begins on precisely this note. Yet Le Corbusier's admiration for Soutter's drawings, accompanied by a vigorous campaign to promote and sell them, was sincere and profound, even as it was also couched in terms that drew attention to their otherness. 'I was dazzled by his immense and intense work, obsessive and inspiring obsession', he would write in 1960 of their first encounter; of the drawings themselves, he affirmed that he held them to be 'of capital value' and 'beyond discussion'. ${ }^{8}$ Le Corbusier made strenuous attempts to interest galleries and collectors in both Europe and America in Soutter - with some success in the United States, where an exhibition at the Wadsworth Atheneum, 
Hartford was the first public showing of the artist's new work - to ease Soutter's pitiful financial state and encourage his practice, and in particular to write about him for the prestigious surrealist-leaning art journal Minotaure. ${ }^{9}$ Published in autumn 1936, and in the company of articles by André Breton and Salvador Dalí among others, 'Louis Sutter [sic]: L’Inconnu de la soixantaine' (translatable perhaps as ‘The Unknown Sexagenarian') presented Soutter's life and mature work to an international audience for the first time, but precisely in terms of the artist's withdrawal from the world at the end, not the height, of a life. 'Why look outside?', he quotes Soutter as saying; 'Complications and attacks on the beauty of Unity. My drawings have no other claim than to be unique and born of an idea impregnated with pain. ${ }^{.10}$

From Soutter's perspective, postcards to his cousin attest not only to his deep admiration of Le Corbusier, but also to a sustained and informed conversation about the latter's work and ideas, since they repeatedly allude enthusiastically to Le Corbusier's writings (as we have seen, Soutter had after all briefly begun a career in architecture); it was presumably in encouragement of this exchange that Le Corbusier gave Soutter a number of his publications, several of which Soutter went on to embellish. ${ }^{11}$ It had become Soutter's practice to draw in cheap school notebooks during the 1920s; by the early 1930s (which is when Thévoz dates the book works), and encouraged by others to take his production more seriously, he began to use better quality papers, ${ }^{12}$ but the decision to draw directly into published books would seem to have been a survival of his interest in working in this small-scale, sequential and 'ready-made' format. More than a dozen such works exist, of which three are made from books by Le Corbusier, and of which five found their way into the Le Corbusier archive. ${ }^{13}$ At least one (and perhaps all) of these was offered to Le Corbusier during Soutter's lifetime, since Une maison - un palais bears a dedication to him on the title page, thus closing the loops of an ongoing dialogue that in each case culminated in a meticulous but destabilized reading of Le Corbusier's books, triggering a surge of imaginative drawings.

What must have attracted Soutter to this idea, however, was that the books in question were already a sophisticated synthesis of text and image, theory and practice. Works of the 1920s such as The Decorative Art of Today struck their readers as innovative and challenging publications, in which each essay was accompanied by a distinctive use of photography as well as drawings (many of them by the architect himself), engravings and facsimile reproductions to create arguments that operated on a visual as well as textual plane. Deeply committed to the idea of books as material objects, Le Corbusier had from early on insisted in executing or controlling nearly all aspects of the design, production and promotion of his publications, from cover design, page layout, typography and format specifications right through to taking on the task of sending out promotional copies and actively pursuing re-editions. ${ }^{14}$ This could make him a particularly demanding - even downright autocratic - author for publishers to deal with, but it also made for results that were unusually closely supervised and meticulously designed in every way, and in which an overt modernity (appropriate to their insistence on completely revising the values of design in its widest sense) vied with a classicism and an insistence on machine production rather than bibliophile's craft that makes them look less like avant-garde artists' books than trade catalogues or technical manuals. ${ }^{15}$

The Decorative Art of Today was typical of these concerns, offering the reader an argument made through text and image interplay that could already be read in more than one way. Composed of articles first published in L'Esprit Nouveau in 1924, this was ostensibly a preparation for the much-heralded Exposition Internationale des 
Arts Décoratifs of the following year. ${ }^{16}$ Far from an endorsement of the exhibition's intentions, however, Le Corbusier's text anticipated the latter's largely conservative, luxury market emphasis by denouncing the whole field of the French decorative arts as an exercise in lazy, superfluous and duplicitous objects and interiors, themselves just the material indicators of a culture and society that had become unfit for purpose. On the one hand, it claimed, the bourgeois taste for luxury and surface pattern removed the object from its functional origins, rooted in human needs; on the other, the nostalgia for craft values set it jarringly at odds with the authentic spirit of the modern age, enshrined in technical design, new technology and mechanized production. If little in all of this looks apt to enthuse Soutter, what is likely to have caught his eye is Le Corbusier's setting of the debate in terms of an irrevocable iconoclasm, and the positing of a return to fundamental human truths through a kind of visual hygiene - echoing strains of destruction and redemption through the image already visible in Soutter's life and work.

But perhaps even more than these features of the text, two aspects of the book's design, both capable of being read in ambivalent ways, also clearly spoke to Soutter. Firstly and most immediately, the book's argument was both made visible and rendered dynamic through a large number of photographic, drawn and engraved illustrations that sometimes simply showed the objects under discussion - whether for approbation or critique - and sometimes set up tensions and questions for the text. Chapter title pages in particular could serve the latter function: thus the first chapter, headed 'Iconologie Iconolâtres Iconoclastes', was accompanied by a photograph of an ostrich peeping balefully over a wire fence, while chapter two on museums opened provocatively with a trade catalogue image of a bidet (plate 1). Where many of the images were of products, interiors and industrial design, particularly of modern transport and office equipment, other unexpected pictures included monkeys playing musical instruments, the music hall artiste Mistinguett, a boxing match and the rings of Saturn. Clearly, if in many places these supported the book's rationale, in others (and to a contemporary audience not long before exposed to the absurd humour of Paris dada, for example) they were capable of being read in less stable terms. ${ }^{17}$ Secondly, and just as crucially for Soutter's project, Le Corbusier's books of this period all feature a careful attention to the qualities of the margin, giving argument and images space, rhythm and dramatic pauses. The generous use of not so much blank as white space forms the defining and contextualizing elevations of a paper architecture that, in the case of The Decorative Art of Today, resonated with the book's insistence on an aesthetic of whitewash, undecorated surfaces and industrial media as elements of a new mental and material hygiene. But to an artist for whom any paper surface presented both an invitation and a compulsion to draw, these were the very spaces in which Soutter's imagination could ferment; as Thévoz notes, the apparent horror vacui observable in so many visionary artists might for Soutter make any white page an interrogation, 'constantly reflecting back to him that unbearable gaping lack to be stitched together at all costs.' ${ }^{18}$

In one sense, and in all probability in the artist's own eyes, Soutter's embellishment of this and the other books by Le Corbusier seems intended as a sensitive, playful but respectful illustration of his cousin's work. ${ }^{19}$ The drawings are expansive and imaginative, but for the most part they consist of fine pen lines that resemble engraving, with a precision that sets up a lively relationship with the books' illustrations, especially the use of found prints from trade catalogues or technical manuals and (particularly in the latter sections) the architect's own architectural sketches. With great care, and however intense their activity, the new images rarely 
I Le Corbusier, page 15 of L'Art décoratif d'aujourd'hui, Paris: G. Crès, 1925.

Norwich: University of East

Anglia. (C) FLIADAGP,

Paris and DACS, London.

Photo: Archives and Special

Collections, University of East

Anglia Library.
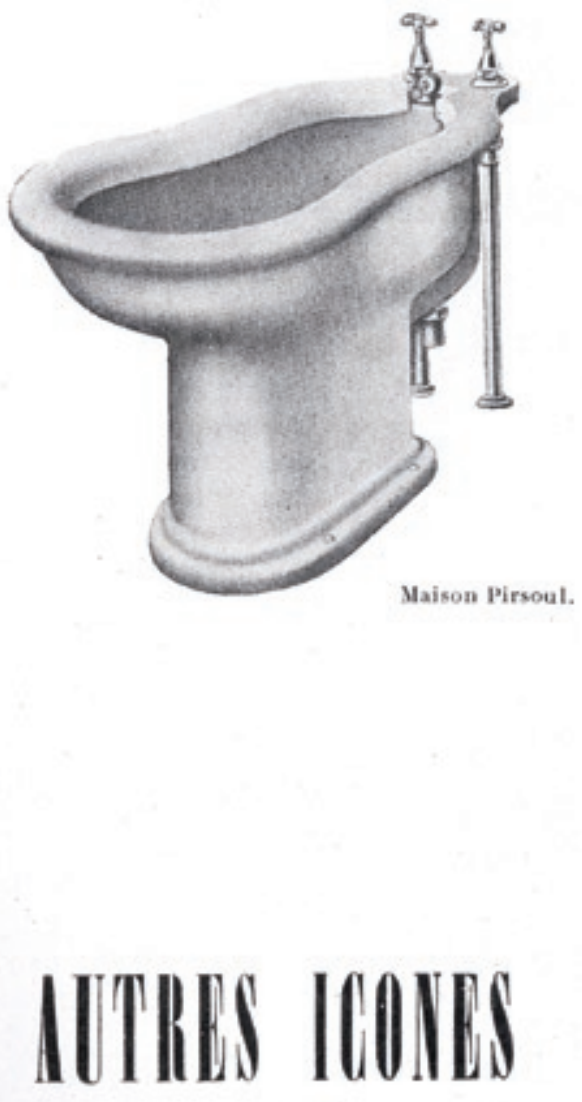

IIIS MISílis

Il y a les bons musées, puis les mauvais. Puis ceux qui ont pêle-mêle du bon et du mauvais. Mais le musée est une entité consacrée qui circonvient le jugement.

intrude upon the existing illustrations of blocks of text, which both remain legible and are now often given a frame or frieze to honour their weight; that each page of drawings is different, that they are usually occasioned by the text or images themselves, and often feature marginal notes, makes Soutter's work a meditative reading that seems to desire a genuine engagement with each book's discourse. The fact remains, nevertheless, that at the level of its explicit argument, and whatever the sincerity of the intellectual accord between the two men, almost every claim made 
by The Decorative Art of Today seems fundamentally opposed by Soutter's vision. Even as the book enshrines through its very design the demand to reject the decorative for the unadorned, the personal for the universal, Soutter's ink drawings not only colonize the uncluttered, meditative space of the margins with a horde of dark designs; their tendency is to completely undermine the book's logic by re-contextualizing and sometimes reinterpreting its images, or by prising words or phrases out of the text and shifting their meaning.

Soutter's re-imagining of the opening page of chapter two of The Decorative Art of Today - marshalled under the image of a bidet - is a particularly complex and

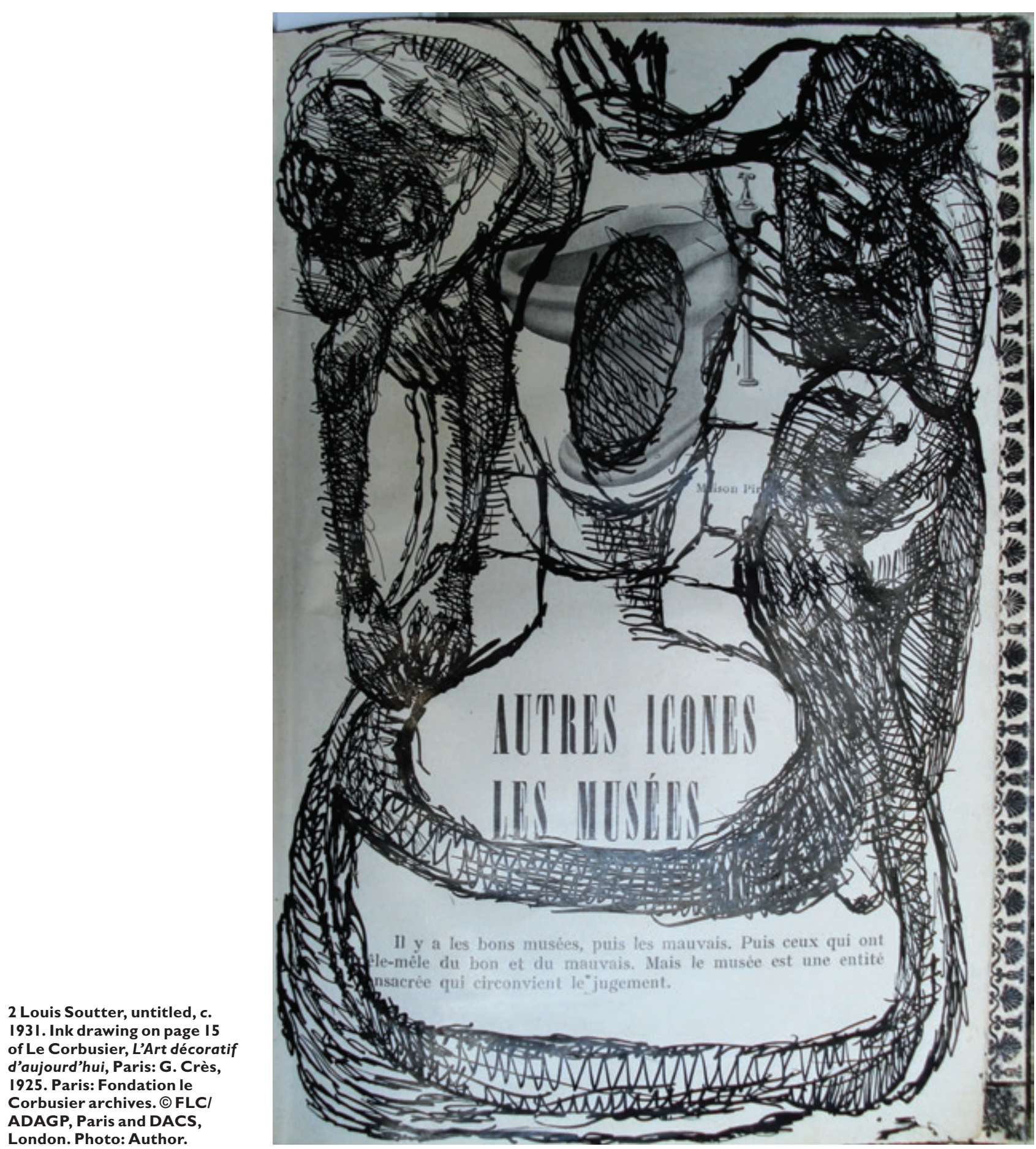


ambiguous drawing (plate 2). While the photograph of the bidet - that paragon of contemporary sanitation, striking in its functional simplicity and supporting Le Corbusier's wider polemic about the daily hygiene epitomized by modern design seems directly to the point, the chapter itself is titled 'Other Icons: Museums'. The brief first paragraph distinguishes good and bad museums, and then suggests: 'But the museum is an acknowledged entity that circumvents judgment.' Onto this - and, for once, allowing himself to draw over the existing illustration as well as around it - Soutter has installed two (apparently nude female) figures, their faces hidden from us as they look towards the bidet, their loose limbs stretching around the space (one figure seems to have a surfeit of hands, of which one is raised dramatically above the bidet) in an entanglement of skeins of roughly cross-hatched and hair-like fabric. Drawn upon the bidet is an upright oval whose shape echoes the plan of the bidet's seat (and now implies a lavatory too), but below this, new lines also suggest that this is the flattened mouth of a bottle whose neck and shoulders are outlined in such a way as to give the two figures a role as both supporting or protecting some sacred vessel, and hint at their ambivalent relation to whatever it might contain: the viewer is unsure whether they are about to sample it, have already done so or, on the contrary, forbid each other its pleasures. A 'judgment' seems indeed to have been made after all, but it is one whose decision remains unavailable to us.

Soutter's responses to the photographs of The Decorative Art of Today in particular work in a number of parallel ways, with the artist often particularly drawn to the very images Le Corbusier had selected in order to ridicule specific design tendencies - noticeably in the images of baroque palace interiors or the visual essay 'Témoins' ('Witnesses') of recent trends where ornamental excess is juxtaposed with industrial design - in order to install a new set of embellishments of his own. Elsewhere, photographs might be added to, expanded or radically re-contextualized through drawing, and in several cases entirely reinterpreted - as when an already rather unexpected photograph of the entomologist Jean-Henri Fabre at his table is rotated by Soutter through $90^{\circ}$ to discover an entirely different figure in the shadows of the image - in ways reminiscent of avant-garde interpretative techniques such as Salvador Dalí's paranoia-criticism. ${ }^{20}$

At the level of the book's writing, many of Soutter's drawings incorporate words or phrases quoted from the adjoining printed text - indeed, it seems reasonable to suppose that these were jotted down first before the drawings were made. But the effect of borrowing these key isolated elements is both to remove specific terms from a wider argument, and in some cases to read these entirely against the grain - most startlingly where Le Corbusier's plea for the establishment of an 'échelle humaine' (human scale) on page thirty-nine is illustrated in a literal but now contradictory manner on the facing page by a tragic figure clinging to a ladder (échelle), the folds of his clothes turning to roots beneath him (plate 3). While the short text contrasts society before and after the advent of mechanization, proposing that what is essential for the latter is the eradication of the former's 'slum' and 'hierarchical décor' alike, each of the three figures inserted by the artist seems in different ways to activate something of the pathos and humanity of both of these spaces. In their contrast to Le Corbusier's upright, assertive and heroic Modulor silhouette (developed during the 1930s and 1940s) - man as the measure of all construction - these slumped but vivid characters endure without denying the tyranny of material life. Where the Le Corbusier posits 'human scale' as proportion, what is laid bare in Soutter's figures is the first rungs of a scale of dignity and existence. Repeatedly, then, Soutter's desire to remain faithful to the text in fact confronts its sense from within, both providing 


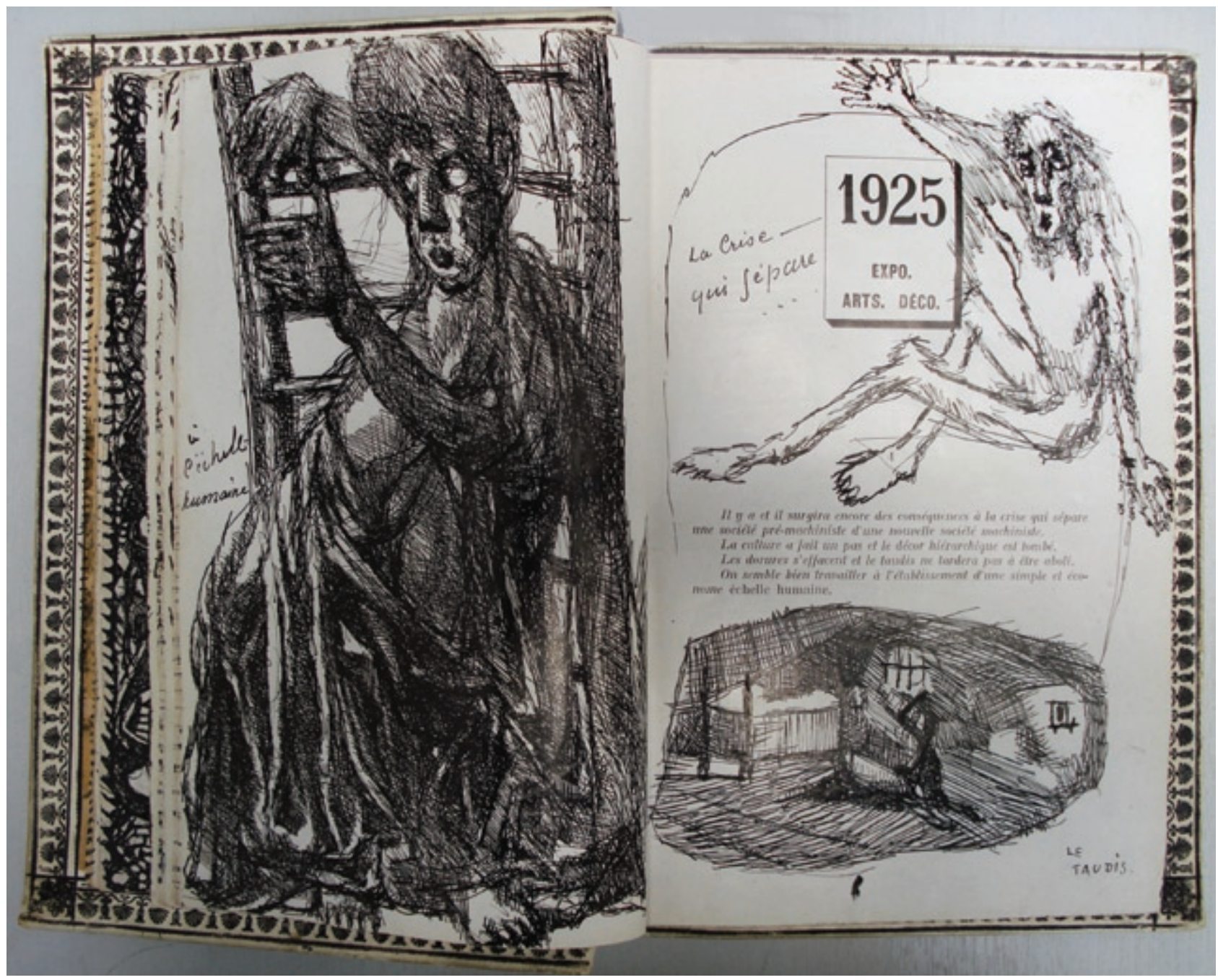

3 Louis Soutter, untitled, c. 193I. Ink drawing on pages 38-9 of Le Corbusier, L'Art décoratif d'aujourd'hui,

Paris: G. Crès, 1925. Paris: Fondation le Corbusier archives. () FLC/ADAGP, Paris and DACS, London. Photo: Author. an ambivalent anchor for his own drawings and sparking tensions that appear to emanate from the book's own logic. ${ }^{21}$ In a more physical sense, too, the effect of Soutter's art has been not only to undermine but to dismantle Le Corbusier's carefully planned work. In addition to its profuse new drawings, this re-titled copy of L'Art décoratif d'aujourd'hui / La Peinture moderne includes tipped-in reproductions of artworks from another source (paintings and woodcuts by Holbein or Dürer, for instance) that are significantly not themselves drawn over by Soutter, as though these represent a further level of intertext through collage rather than drawing. Just as puzzlingly, scrutiny of the bound volume reveals that whether by accident or design the pages of the original books are often no longer in the correct order, and others are missing altogether: presumably, so as to facilitate the process of drawing on them, it would seem that Soutter physically dismantled each book before constituting it anew, a process of destruction, interpretation and re-making that pits Le Corbusier's utopian rhetoric against Soutter's visionary struggle between text and image.

Most tellingly, of course, Soutter's challenge to the argument of The Decorative Art of Today - with its uncompromising rejection of ornament, nostalgia and surplus operates above all by sending the book spinning back to the world of the 'decorative', albeit now a decoration that appears excessive, occult and self-sufficient, apparently rooted in an archaic world of form, and as foreign to the bourgeois love of the exotic surface as to Le Corbusier's rationalized 'type objects'. A substantial number of 
4 Louis Soutter, untitled, c. 193I. Ink drawing on pages 74-5 of Le Corbusier, L'Art décoratif d'aujourd'hui,

Paris: G. Crès, 1925. Paris: Fondation le Corbusier archives. @ FLC/ADAGP, Paris and DACS, London. Photo: Author.
Soutter's drawings in this book consist of thickly coiled decorative marginal designs crowded closely around the text and illustrations, reminiscent sometimes of skeins of rope or hair (and on occasion suggesting a morphology of entire bodies), sometimes of organic fibres or shells, apparently - and in flagrant contradiction to the book's stipulations, mocking the geometry of its rationalized objects - bereft of any function other than to lose the viewer in their spirals (plate 4). Curlicues and nodes sometimes branch out from the illuminations, reaching into the line breaks as though to actualize the relationship between text and drawing, or invite a tentative reading based on a phrase or subtitle. Thévoz observes that decorative motifs form a recurrent theme within Soutter's oeuvre, and that on occasion he would use the pretext that they were designs for proposed embroidery or weavings, reading these spirals and labyrinths as an invocation of the interior life of the family, as well as of the broken maternal link driving part of Soutter's inner turmoil. ${ }^{22}$ Despite the conflict between Soutter's commitment to ornament and the book's blunt rejection of it, it is important to note that Le Corbusier's own earlier interests in the decorative arts were themselves far more open to the decorative or the organic. ${ }^{23}$ In this light, Soutter's superimposed drawings might be read as a kind of reawakening of his cousin's disavowed past.

If these anxious labyrinths seem distinctly out of kilter with the harmony and order of Le Corbusier's conception of both the social and the private environment, they nevertheless point to the fact that Soutter's drawings in these books tend invariably to collapse space, notably by flattening the picture plane, ignoring

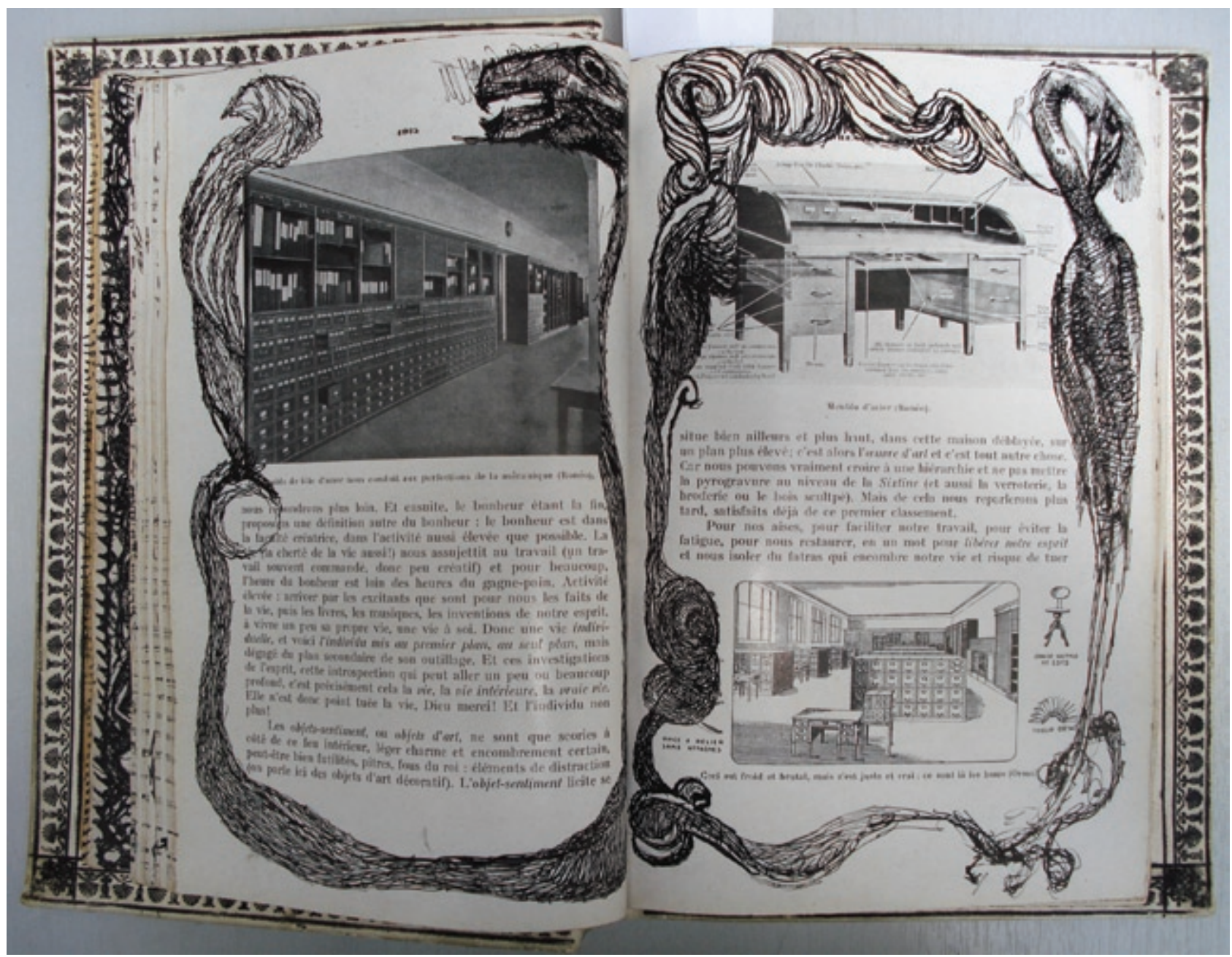




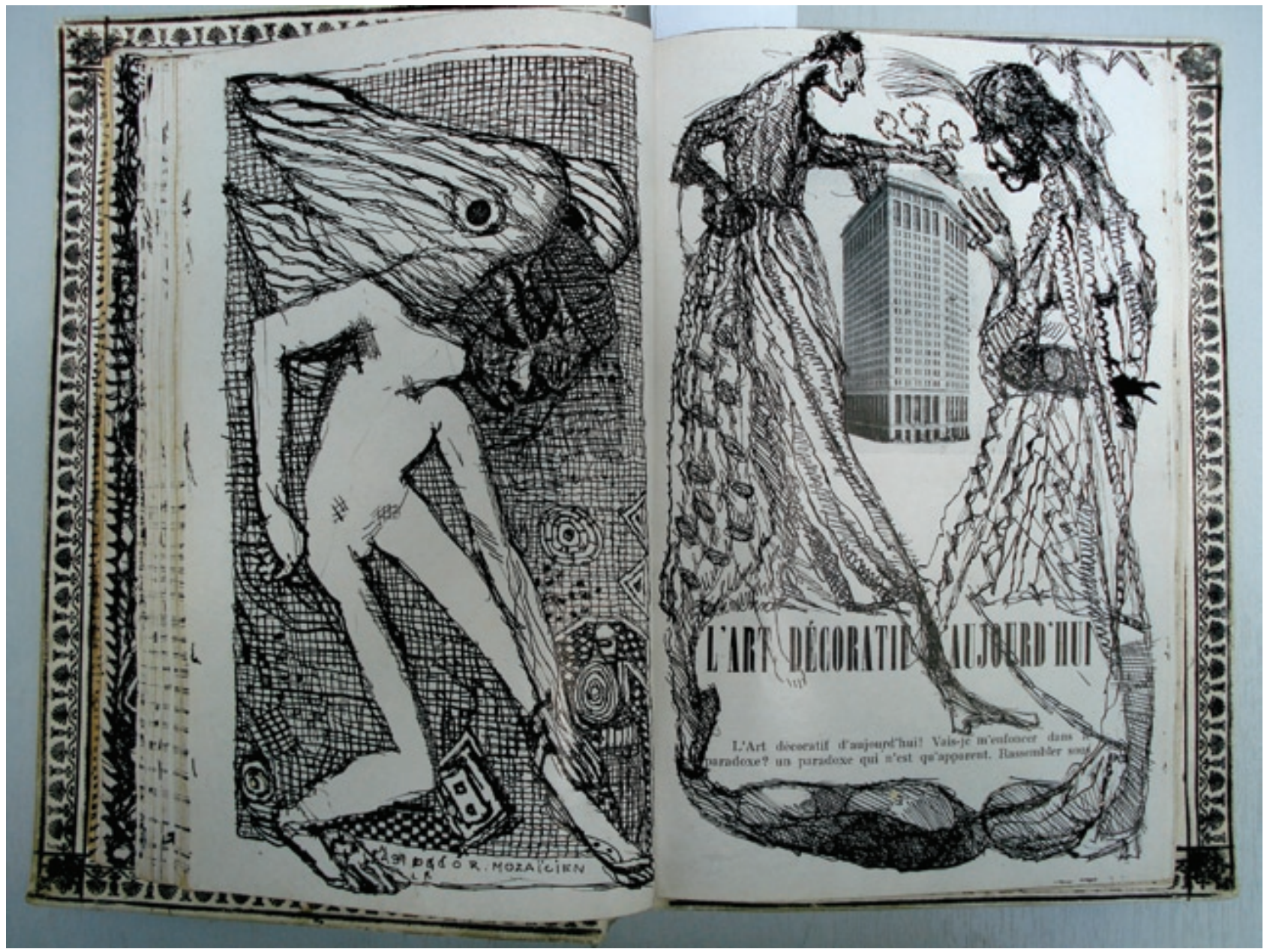

5 Louis Soutter, untitled, c. 193I. Ink drawing on pages 82-3 of Le Corbusier, L'Art décoratif d'aujourd'hui, Paris: G. Crès, 1925. Paris: Fondation le Corbusier archives. @ FLC/ADAGP, Paris and DACS, London. Photo: Author. perspective, and above all by crowding the page with superimposed lines and figures. Space in Soutter's work, as Thévoz notes, is closed in on itself, denying the viewer a sense of distance from it: it 'imposes upon us an anxious proximity to everything' until we feel trapped in the space of the self, so that the artist "makes us experience space itself like a form of captivity'. ${ }^{24}$ Indeed, an obsessive inwardness in the specific context of the built environment was the motif under which Le Corbusier had begun his article in Minotaure, which opened by quoting Soutter: 'The minimum dwelling, or the "future housing unit" must be made entirely of translucent glass. No more windows, those useless eyes. Why look outside?', the architect going on to note that this idea lies 'at the very opposite of my own ideas, but it manifests the thinker's intense inner life'. ${ }^{25}$

While Soutter's claustrophobic configurations may appear the mirror reverse of Le Corbusier's aesthetic of light and harmony, Soutter's language here again suggests a clear familiarity with his cousin's ideas (indeed, the polemical styles of both men bear some similarities). What is more, his drawings in L'Art décoratif d'aujourd'hui and other books by Le Corbusier repeatedly represent architectural space, whether that of ancient and imaginary cities (chiming with the book's reproduction of the architect's own sketches of the city of Istanbul, for example), the modern world of high-rise edifices redolent of the new American skyline, or specific designs by Le Corbusier; in all three, the city or building as fortified bastion or as utopian reverie suggest a powerful metaphor for the self whose psychological echoes can be found in both men's work, however different their respective outlooks (plate 5). ${ }^{26}$ 
6 Louis Soutter, untitled, c. 193I. Ink drawing on page I of Le Corbusier, Une maison - un palais, Paris: Éditions Crès, 1928. Paris: Fondation le Corbusier archives. $\odot$ FLCl ADAGP, Paris and DACS, London. Photo: Author.

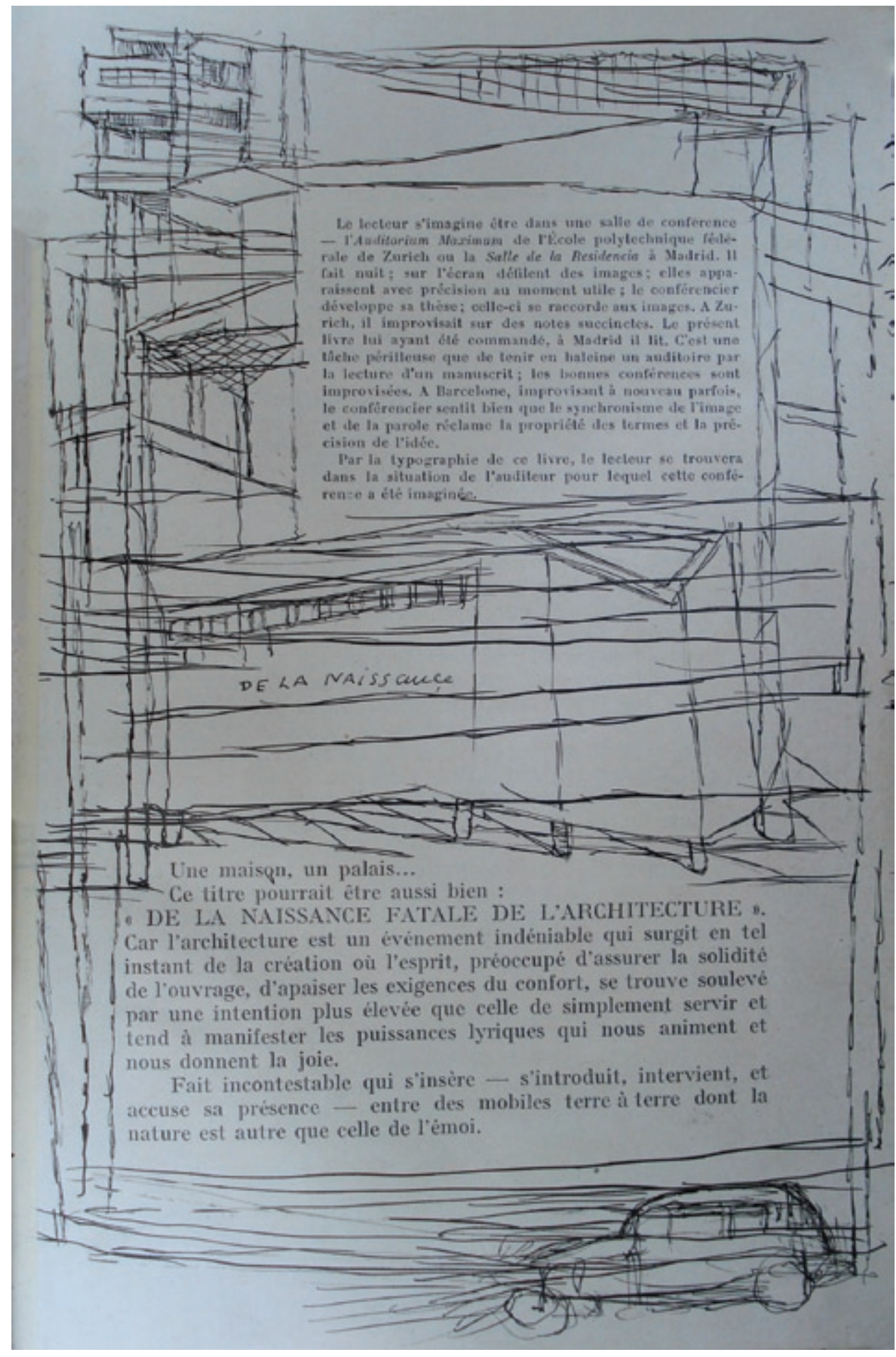

In particular, the three-quarter outline of a typical Le Corbusier concrete skeleton 'Dom-Ino' housing unit (first developed by the architect in 1914) appears repeatedly in Soutter's more nervous hand as a kind of magic sign, reincorporated into Soutter's own iconography of an interior life laid bare (plate 6). Elsewhere, photographs of Le Corbusier houses are drawn over, expanded and new occupants installed, the empty interiors or exteriors in the reproductions sometimes abandoned to the jungle, sometimes haunted by wraith-like figures that seem to mock their sanitary logic (plate 7). Soutter's insistence on pursuing this architectural debate, however delirious 
7 Louis Soutter, untitled, c. 1931. Ink drawing on page 73 of Le Corbusier, Une maison - un palais, Paris: Éditions Crès, 1928. Paris: Fondation le Corbusier archives. @ FLC/ ADAGP, $P$ aris and DACS, London. Photo: Author. the results, Thévoz suggests, represents not simply a desire to engage his cousin but an urge to absorb the latter's identity, 'a tendency to identify unconsciously with a powerful and prestigious individual' in the person of the architect. ${ }^{27}$ Yet for all that these drawings may be read as an internalization of Le Corbusier's text and theories, they nonetheless also signal a kind of triumph over the latter's own rationalizing and totalizing ambition, through the medium of the line. Architecture and drawing are fundamentally opposed, Le Corbusier claimed in Croisade ou le Crépuscule des Académies (one of the books Soutter was to embellish); drawing was the enemy. ${ }^{28}$ Under Soutter's pen, for a moment at least, this model of conflict could be resolved at a stroke in an alternative utopia of architecture and the imagination (plate 8).

Sensitive from the outset to the presumption of defacing Le Corbusier's books, ${ }^{29}$ Soutter also seems to have been well aware of the manifest contradictions between the world views their respective systems represented, writing to his cousin in January 1936: 'I shan't make any more of these drawn-over books, it's contrary to your thought.' ${ }^{30}$ It is tempting to read this respectful curbing of the desire to engage Le Corbusier through overlaying one vision upon another as an avowal of Soutter's own anxious, ill-adapted demeanour, a lucid moment in what his commentators have seen as a kind of schizo-text played out both in these extraordinary one-off books and in his work as a whole, in the face of Le Corbusier's calm, monumental thought. Yet in the meeting of these two apparently mutually exclusive worlds it might be said that both show signs of instability and difficulty, and that the two men's encounter is characterized just as much by a shared ambivalence as by an unequal relationship between a troubled individual encouraged and supported by his younger but psychologically secure confidant. One small but telling detail relates to Le Corbusier's own designations of selfhood. For all his muscular public

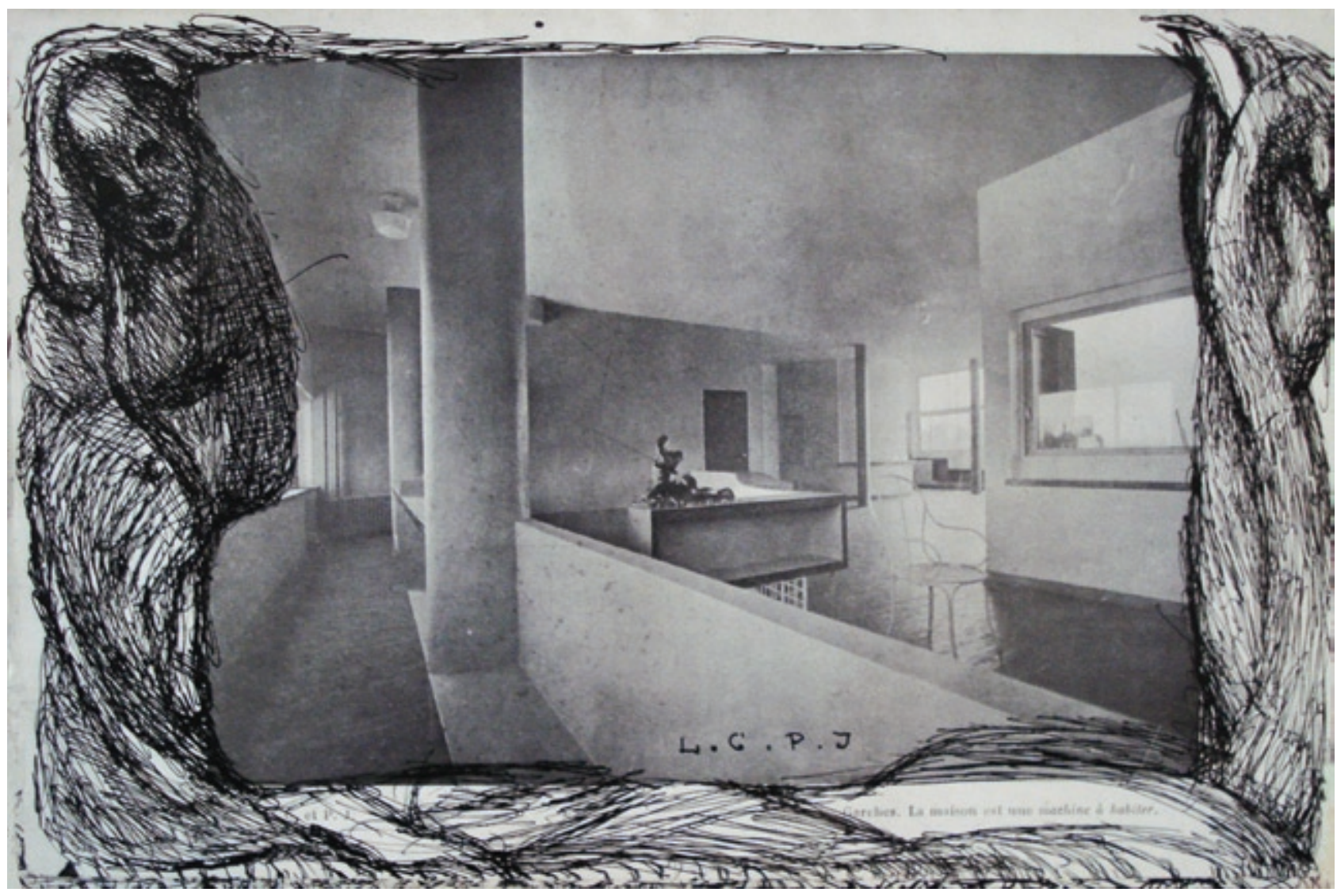


8 Louis Soutter, untitled, c. 193I. Ink drawing on page 60 of Amédée Ozenfant and Charles-Edouard Jeanneret, La Peinture moderne, Paris: Éditions Crès, 1925. Paris: Fondation le Corbusier archives. @ FLC/ADAGP, Paris and DACS, London. Photo: Author.

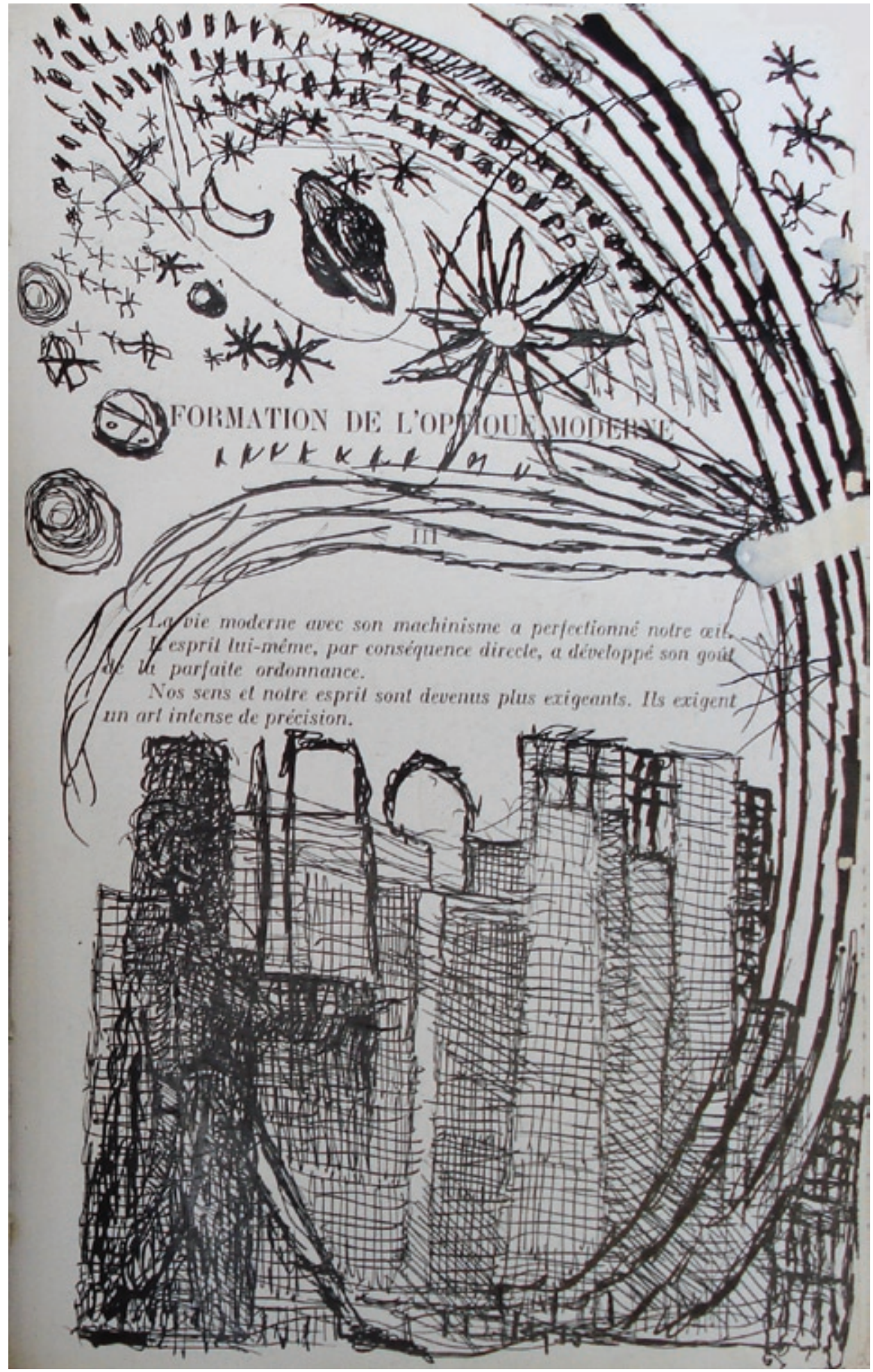

persona, Charles-Édouard Jeanneret himself repeatedly indulged in games with his identity, inventing several pseudonyms, playing with versions of his chosen name and frequently adopting an ambivalent authorial voice in his writings to the extent that this identity is often under construction; yet on more than one occasion he seems to have hesitated over that of his cousin as well, in the varied spellings of Soutter's surname. ${ }^{31}$ 
While Soutter's work has been read as a sublimation of his own intolerable feelings of failure and insecurity, the apparently entirely self-confident Le Corbusier, too, shows signs in his writings of a nagging anxiety about failure, with letters, texts and entire books driven by the desire to redeem unsuccessful projects or defend the author against criticism. ${ }^{32}$ And although Soutter's obsessively repeated figural drawings, particularly those of women, have been interpreted by commentators as indicative of an unstable and paranoid anxiety over sexual relations, the relationship between Le Corbusier's own work or behaviour and issues of gender, power and the gaze have also been questioned, with the problematic overlaying of the female body onto the object, the building or the city a repeated motif in his visual practice, and instances of the fetishization or disavowal of objects and materials visible throughout his theoretical writings. ${ }^{33}$ Finally, an uncomfortably close intertwining of architecture and institution haunts the two men's writings to and about each other. While Soutter dreams, in his letters and his drawings on the books, of an ideal but modest 'minimum dwelling' (perhaps one designed by his cousin) to which he can escape from the misery of institutionalization, ${ }^{34}$ Le Corbusier speaks of the 'hygiene' of the Maison de Jura, of its ideal situation within a natural environment, in terms that make it more than a little unclear if he sees this building as a place of incarceration or refuge. ${ }^{35}$ While Soutter's experience of drawing over the work of others seems to have been an intimate and self-contained experiment, Le Corbusier would come to adopt this practice himself in public, through the use of drawing upon photographs, book jackets and texts in his own publications after Soutter's death, and perhaps as a direct result of his cousin's influence. ${ }^{36}$

In the end, perhaps, these two modes of being, these two visions, find themselves in the Le Corbusier-Soutter books not so much overlaid by their chance encounter as organically and inevitably grown together, feeding into each other's structures until it becomes hard to read The Decorative Art of Today, for example, without sensing the afterimage of Soutter's ghosts between its pages, without seeing Soutter's fevered drawings as somehow completing and immunizing the unity of Le Corbusier's vision of harmony by injecting it with all the qualities of its negation. Le Corbusier would write to his cousin in 1936, the year he published his text on this 'inconnu':

You see, Louis, one mustn't wish for what's inaccessible. You have a drawing style that brings you a wonderful chance to bring to the world what you have in your heart. ... I often talk about you with great admiration. I show your beautiful drawings. Draw, Louis, that's happiness. And know that I'm your friend. ${ }^{37}$

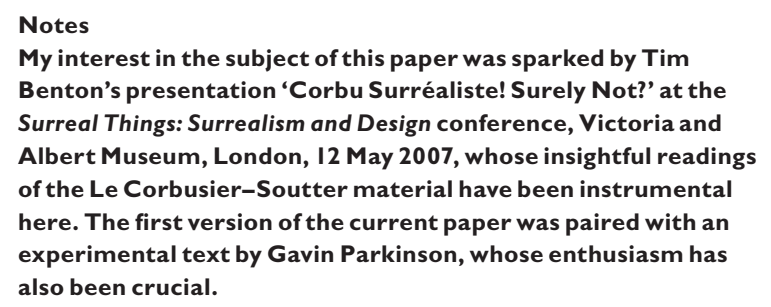

1 On this last claim, see for example Alexander Gorlin, 'The ghost in the machine', in Thomas Mical, ed., Surrealism and Architecture, London 2005, $103-18$.

2 Michel Thévoz, Louis Soutter: Catalogue de l'œuvre, Lausanne, 1976, catalogue entries 2475 and 2476 .
3 Discussions of Soutter's work frequently cite the relationship between the two men, but the books in question have been considered in two principal locations: Michel Thévoz, Louis Soutter ou l'écriture du désir, Lausanne, 1974, 45-56; and Armin Zweite. "'Keine Fenster mehr, diese unnützen Augen”: Louis Soutter und Le Corbusier oder Geflecht und Geometrie', in Zweite, ed., Louis Soutter (1871-1942): Zeichnungen, Bücher, Fingermalerien, Munich, 1985, 47-72. Thévoz also discusses the relationship in more general terms in his other major study of the artist (first published in 1970), Louis Soutter, Lausanne, 1989, 58-9. In the literature on Le Corbusier, besides Tim Benton's unpublished paper cited above, the only location to our knowledge where the books are discussed is the extensive consideration of the relationship between the two men in Daniel Naegele, 'Drawing-over: Une vie décantée. Le Corbusier y Louis Soutter', Revista de Arquitectura, 6, June 2004, 43-54 (http://fast-ip.org/naegele.pdf); and a brief mention of 
them in Catherine de Smet, Vers une architecture du livre. Le Corbusier: édition et mise en pages 1912-1965, Baden, 2007, 29. Since the present paper was first written, however, several more recent sources have appeared which have extended the visibility and discussion of the relationship and collaboration of the two men. One is a full facsimile reproduction of Une maison - un palais, Lyon, 2011, with a postscript by Julie Borgeaud; there have also been two exhibitions featuring the artist's book-based works Le Corbusier, Louis Soutter, croisements, La Maison Blanche de Le Corbusier, La Chaux-de-Fonds, 2010 and Fondation Suisse, Paris 2012, and Louis Soutter: Le Tremblement de la modernité, Maison Rouge/Fondation Antoine de Galbert, Paris 2012 (all curated by Borgeaud, who was also responsible for the latter exhibition's catalogue). Caroline Levitt, who has also been working on this material, was kind enough to share the text of her conference paper 'Criminal or cousinly? Louis Soutter's ornamentation of Le Corbusier's treatises' (2012).

4 Biographical material on Soutter in this section is drawn from the first part of Thévoz, Louis Soutter (1989).

5 Thévoz, Louis Soutter (1989), 70; see also Lucienne Peiry, L’Art brut, Paris, 1997, 143 and 215. In terms of Soutter's status as suffering from a mental illness, Thévoz underlines (Louis Soutter (1989), 35) that the Asile de Jura was a home for the elderly, largely inhabited by rural paupers placed in care by their communes, and notes elsewhere (140) that Soutter was never formally diagnosed or treated for mental illness. As Thévoz suggests, if the biography of the artist and anecdotal evidence of his behaviour show clear signs both of Freud's notion of 'melancholia' and of schizophrenia, the work might on the contrary be seen precisely as a strategy through which full-blown mental illness was kept at bay (28-30 and 44-6); Thévoz also argues not only that speculation about Soutter's mental illness is irrelevant for the work, but that it has also been used as a way of avoiding its truths (140-2). Naegele, on the other hand, notes the potential echoes between the artist's art brut status and Le Corbusier's contribution to what has been termed 'brutalist' architecture ('Drawing-over', 45).

6 The passing reference to Soutter in Hal Foster et al., Art Since 1900: Modernism, Antimodernism, Postmodernism, London, 2004, 478, for example, typifies this quandary (on a subject for which one might expect its authors to have some sympathy). Wrongly cited as an untrained artist, Soutter's name is mentioned simply by way of an example of Dubuffet's category, this discussion in turn occasioned only in order to support a discussion of the post-war German painter Georg Baselitz. Julie Borgeaud's research and publications (see note 3 above) rightly correct the reception of Soutter as isolated from avant-garde culture.

7 Thévoz, Louis Soutter (1989), 10 and 58; Thévoz, Louis Soutter ou l'écriture du désir, 14.

8 Le Corbusier, letters to the Musée de Beaux Arts, Lausanne, 21 December 1960, John Nef, 6 March 1936, and Marguerite Tjader Harris, 9 September 1937. But Le Corbusier's claims about Soutter's work could shade into a claim over it: 'I am the one who discovered Louis Soutter and who encouraged him for 7 or 8 years to pursue his drawing', he would write on 16 October 1936 to the writer Jean Giono (all letters from the archive of the Fondation Le Corbusier, hereafter referred to as FLC).

9 Le Corbusier, correspondence with James Thrall Soby and Tériade, FLC archive; the latter in particular testifies Le Corbusier's impatience and frustration with delays with the Minotaure article. A postcard from Soutter (7 December 1931, FLC archive) thanks Le Corbusier for money in terms that indicate how precious it was: 'I was able to buy the indispensable: Shoes. Stamps. Ink.'

10 Le Corbusier, 'Louis Sutter: L'Inconnu de la soixantaine', Minotaure, 9, October 1936, 62-5. This issue is, arguably, one of those least dominated by surrealist ideas, with articles on Matisse, Cézanne, Cranach and a technical discussion of the effect of artificial light on plants; perhaps this placement, and the delays in publication, reflect the well-known antipathy among surrealists towards Le Corbusier. On the other hand, both the surrealist enthusiasm for what would later be termed art brut, and the affinities discerned by several subsequent commentators between Soutter's work and surrealist practice - notably in considering his drawing as a kind of automatic process, but even in the echoes between Soutter's 'why look outside?' and Breton's 'inner model' for surrealist painting - makes Minotaure a highly appropriate location for this text. After the war, Soutter's work would also be published in the French surrealist journal Troisème convoi.

11 The FLC archive holds a number of postcards and letters from Soutter and a few typescripts of Le Corbusier's letters to him, as well as typescripts of his letters to others to promote Soutter's work. Soutter's postcards of 3 November 1931, 30 January 1936 and 19 June 1939, for example, all mention his avid readings of Le Corbusier's books, the first of these being Une maison - un palais. The tone of the correspondence between the two men attests to a warm and frank friendship, but one that also suggests a level of serious intellectual exchange as well.

12 Thévoz, Louis Soutter (1989), 63.

13 Thévoz, Louis Soutter: Catalogue de l'œuvre, 300-8. Besides the Le Corbusier volumes already cited, Thévoz also lists Soutter's embellishment of Le Corbusier's Croisade ou le Crépuscule des Académies (1933) (cat. 2468). The Fondation archive contains, as well as the two volumes already cited, copies of Gustave Flaubert, Salammbô (undated), François Mauriac, Le Baiser au lépreux (1926), and Marcelle Vioux, Les Amants tourmentés (1929), all richly illustrated with Soutter's drawings.

14 De Smet, Vers une architecture du livre, see for example page 9. This work is a detailed study of both the design and the editorial process of Le Corbusier's books.

15 De Smet (Vers une architecture du livre, 30ff.) notes, as others have done, that Le Corbusier's book designs are generally conventional in appearance when compared, for instance, to contemporary Bauhaus publishing design (see also the same author's catalogue Le Corbusier: Un architecte et ses livres, Baden, 2005, 72). On the relationship between Le Corbusier's books of the 1920s and trade catalogues or publicity material, see Beatriz Colomina, Privacy and Publicity: Modern Architecture as Mass Media, Cambridge, MA, 1994, 141-53.

16 Le Corbusier, L'Art décoratif d'aujourd'hui (1925), Paris, 1980.

17 De Smet, in Vers une architecture du livre, 30, cites Élie Faure writing in 1935 about Le Corbusier's books of this period: 'Remember this unique presentation, at first sight chaotic but composed with such malice. Remember those original illustrations using unexpected photographs - sometimes lovely, sometimes laughable ... always with the intention of soliciting the rigour of a logic that nails the reader's thought like a stroke of good luck. It shakes him, tickles him, knowing that he's an unsympathetic dimwit. It pinches him mirthlessly, and makes him first frightened then indignant.' Several commentators have noticed the potential parallels (and divergences) between Le Corbusier's use of text and image juxtapositions and dada strategies (see for example Colomina, Privacy and Publicity, 170-85; De Smet, Le Corbusier, 72). A single, doubtless isolated but extraordinary example exists of Le Corbusier's ability to manifest his interest in the material qualities of the book in startling ways: his library copy of Don Quixote, bound in the hide of his long-haired dog Pinceau (De Smet, Vers une architecture du livre, 29).

18 Thévoz, Louis Soutter (1989), 44 and 76. Though Thévoz's methodological grounding tends to lie in Freudian psychoanalysis, here he is playing on an affinity between the notion of stitching together (as with a wound): suturer, and the artist's own identity that might be consistent, for example, with a wider Lacanian reading of Soutter's work.

19 A rather different reading is acknowledged by Le Corbusier, in writing to Jean Giono of an unrealized project to include Soutter's drawings in one of the latter's books: 'I do not believe him psychologically equipped enough to be able to complete what's termed an "illustration" of a text in the usual sense of the word. On the other hand ... in my opinion there are enough materials in his work to be able to select those drawings that could add something like a profound echo of the text in which they were inserted' (letter of 16 October 1936, FLC archive).

20 One must for the moment leave open the question of whether Soutter might indeed already have been aware of such strategies in contemporary practice, in the face of his usual definition as an isolated art brut 'outsider'. Correspondence from Soutter to Le Corbusier (for example, 8 November 1937, FLC archive) several times indicates that the former was familiar with the journal Minotaure (which of course published the latter's article on Soutter), dominated in particular by surrealist ideas and containing some of Dalí's most 
interesting writing; but the journal postdates Thévoz's dating of the book drawings. If nothing else, Soutter was obviously exposed to debates around the early twentieth-century Parisian avant-garde through Le Corbusier himself, and books like La Peinture moderne. It is on the subject of avant-garde painting and sculpture, including purism, that Soutter allows himself his most explicit criticisms in the section of this bound volume made from Le Corbusier's and Ozenfant's La Peinture moderne. Where on pages $40-1$ the text claims that nature is only beautiful in the context of the perfect geometries of art, Soutter adds in pencil: 'On the contrary!! The imperfection of art only occurs when the so-called geometrical element is disturbed'; page 122's reproduction of a cubist harlequin by Picasso provokes Soutter's comment 'Useless comprehension', while a Lipchitz relief is simply captioned 'nul' ('worthless').

21 See Thévoz, Louis Soutter ou l'écriture du désir, 55-6.

22 See Thévoz, Louis Soutter ou l'écriture du désir, $110 \mathrm{ff}$.

23 See, for example, Stanislaus Von Moos, Le Corbusier: Elements of a Synthesis, Cambridge, MA, 3-7 or Nancy J. Troy, Modernism and the Decorative Art in France: Art Nouveau to Le Corbusier, New Haven, CT and London, 1991.

24 Thévoz, Louis Soutter ou l'écriture du désir, 94 and 100.

25 Le Corbusier, 'Louis Sutter', 62.

26 Thévoz, Louis Soutter ou l'écriture du désir, 180-1.

27 Thévoz, Louis Soutter ou l'écriture du désir, 50.

28 Thévoz, Louis Soutter ou l'écriture du désir, 147. On the other hand, as Beatriz Colomina points out in the context of Le Corbusier's practice, the architect could also figure drawing as crossing a threshold of privacy when he writes, 'By working with our hands, by drawing, we enter the house of a stranger, we are enriched by the experience, we learn' (cited in Colomina, 'Battle lines: E.1027', in Diana Agrest et al., eds, The Sex of Architecture, New York, 1996, 167-82 (175)). When we know how problematic Soutter's search for home was - the impossibility of entering other people's environments without disruption, the despair at his being housed against his will - it's tempting to imagine Soutter's drawing as an entry (a return?) into the dwelling of his own kin in just this way.

29 'Started sketches on La Maison. Un Palais. [sic] Don't scold me for this impertinence. In any case I shall read it all' (postcard from Louis Soutter to Le Corbusier, 12 October 1931, FLC archive).

30 Louis Soutter, postcard to le Corbusier, 21 January 1936, cited in Thévoz, Louis Soutter ou l'écriture du désir, 56.

31 Le Corbusier apologizes to Soutter for the surprising misspelling of his name in the Minotaure article and attributes it to a printing error (letter to Louis Soutter, 24 November 1936); but Le Corbusier repeats the slip in other correspondence, giving it again as Sutter throughout a letter to the Musée des Beaux Arts, Lausanne, 21 December 1960, or as Souter throughout in his letter to James Thrall Soby, 17 January 1936 (all letters FLC archive).

32 One such book is precisely Une maison - un palais, written partly as a riposte to the rejection of Le Corbusier's plan for the League of Nations headquarters in Geneva in 1927. As with several other examples of unrealized designs during this crucial period, it was precisely the architect's most ambitious and defining projects that suffered this fate.

33 On Soutter's representations of women, see Thévoz, Louis Soutter (1989), 51-2; on Le Corbusier and gender issues, see for example Colomina, 'Battle lines: E.1027'. For a wider situation of Le Corbusier's ideas as an affirmation of an essentially masculine modernity see Tag Gronberg, Designs on Modernity: Exhibiting the City in 1920s Paris, Manchester, 1998; this apparently secure gender identity, clearly, is fatally undermined in the Le Corbusier-Soutter books by the effect of Soutter's drawings.

34 'The Maison le Lac would be a favour you could grant me' (postcard to Le Corbusier, date illegible, FLC archive); 'Where is my life of effort? I think of the Lac, 14 square metres big or more, which could start my career [?] as a painter: I can't cope with this place any longer. Alone. Ville Radieuse, where are you?' (postcard to Le Corbusier, 28 May 1937, FLC archive).

35 'Then it's the rest home, with the many other withdrawn individuals like [Soutter]. The silence of the pine forests all around; the tonic alpine air that keeps the body dry. The bringing together, in this large hygienic house, of the autumns of lives' (Le Corbusier, 'Louis
Sutter', 63). One might recall that the architect had at this point already designed a building for similar purposes, the Cité de Refuge Salvation Army sheltered accommodation for the homeless, Paris 1932.

36 For examples and a discussion of this practice in the context of book design, and the contention that Soutter's work directly influenced Le Corbusier, see De Smet, Vers une architecture du livre, 29 and note 48, and 194-7; Daniel Naegele, 'Drawing-over', 50ff. On a particular instance of Le Corbusier's drawing as a problematic redrawing of public and private spheres, see Colomina, 'Battle lines: E.1027'.

37 Le Corbusier, letter to Louis Soutter, 1936, cited in Thévoz, Louis Soutter (1989), 59. 


\section{'Complications and Attacks on the Beauty of Unity': Le Corbusier and Louis Soutter

\author{
Krzysztof Fijalkowski
}

The sources of Le Corbusier's status as the most influential architect of the twentieth-century may be traced above all to his theoretical writing, as communicated in his own carefully supervised book publications. A detailed and profound response to them comes in the form of unique artist's books made from several of these works by the architect's own cousin Louis Soutter, an artist often categorized as an 'art brut' visionary. This essay examines the ways in which Soutter's dense figurative and decorative marginal drawings on the books emphasize the ambivalent tensions and exchanges between the two men and their apparently contradictory but equally complex world views.

Krzysztof Fijalkowski is Professor of Visual Culture at Norwich University of the Arts. Recent publications include: Surrealism and Photography in Czechoslovakia (Ashgate, 2013, with Michael Richardson and Ian Walker); 'Poétique/Politique: Picasso, Surrealism and Politics after 1944', in Jonathan Harris and Richaerd Koeck, eds, Picasso and the Politics of Visual Representation (Liverpool University Press, 2013); and the translation and introduction of Gherasim Luca's The Passive Vampire (Twisted Spoon Press, 2008). 